diabetes. Most patients have no means of assessing control apart from the presence or absence of symptoms. Home monitoring of blood glucose concentrations is economically impracticable for most patients, but easier access to urine dipsticks would probably increase patients' interest and motivation in improved control and would not add greatly to total direct costs.

The need for inpatient admission should also be considered carefully, especially for newly presenting patients. Wherever possible admission is best avoided if the patient and family are able to receive initial daily outpatient education and supervision. ${ }^{15}$ Patients should be admitted only if they require nursing care or circumstances do not permit easy attendance at outpatient clinics. Admission rates for diabetic patients in Tanzania are six times higher than in the general population. ${ }^{16}$ When patients are admitted careful consideration should be given to the need for investigations. Testing urine four times or more daily for example, may be unnecessary if blood glucose concentrations are also being measured. Consideration should also be given to the period of admission since patients are often kept in the wards until most urine results are glucose free.

The small proportion of direct costs due to nurses' and doctors' services reflects the low rates of pay of medical staff in most sub-Saharan countries. A lecturer in medicine, for example, is paid $\$ 60$ monthly. The reasons for such low rate of remuneration are understood, but attention must also be paid to this problem since the motivation and interest of those caring for patients can have a significant impact on the quality of care.
We thank the director general, colleagues, and staff, of Muhimbili Medical Centre; Professor K G M M Alberti, University of Newcastle upon Tyne; the Ministry of Health, United Republic of Tanzania; the British Council; and the Overseas Development Administration.

1 Laing W, Williams R. Diabetes: a model for health care management. London: Office of Health Economics, 1989:32-49.

2 Fox NA, Jacobs J. Direct and indirect costs of diabetes in the United States in 1987. Alexandria, Virginia: American Diabetes Association, 1988.

3 Johnson B. Diabetes - the cost of illness and the cost of control. An estimate for Sweden 1978. Acta Med Scand 1983;671(suppl):19-27.

4 Triomphe A, Flori YA, Costagliola D, Eshchwege E. The cost of diabetes in France. Health Policy 1988;9:39-48.

5 Vaughan P, Gilson L, Mills A. Diabetes in developing countries: its importance for public health. Health Policy and Planning 1989; 4:97-109.

6 World Bank. United Republic of Tanzania: population, health and nutrition sector review, 1989. Washington, DC: World Bank, 1989.

7 McLarty DG, Swai ABM, Kitange HM, Masuki G, Mtinangi BL, Kilima PM, et al. Prevalence of diabetes and impaired glucose tolerance in rural Tanzania. Lancet 1989;i:871-5.

8 World Health Organisation. World Health Organisation supports world diabetes day. WHO Features 1991 ; No 158 (June): 1-4.

9 Swai ABM . Luta J, McLarty DG. Diabetes in tropical Africa: a prospective study, 1981-7. Characteristics of newly presenting patients in Dar es Salaam, study, 1981-7. Characteristics of

10 Aaron H, Schwartz WB. Rationing health care: the choice before us. Science 1990;247:418-22.

11 Enthoven A. Reforming US health care: the consumer choice health plan. In: Black N, Boswell D, Gray A, Murphy S, Popay J, eds. Health and disease. Milton Keynes: Open University Press, 1984: 335-40.

12 McLarty DG, Kinabo L, Sawi ABM. Diabetes in tropical Africa: a prospective study, 1981-7. II. Course and prognosis. BMF 1990;300:1107-10.

13 Corrigan CB, Ahren B. Ten years' experience of a diabetes clinic in Northern Tanzania. East Afr Med f 1987;64:772-80.

14 Rolfe M, Armstrong JRM. Diabetes mellitus on the Zambian Copperbelt. f R Coll Phys Lond 1989;23:255-9.

15 Scott RS, Brown LJ, Clifford P. Use of health services by diabetic persons. II Hospital admissions. Diabetes Care 1985;8:43-7.

16 Planning Commission. Hali ya Uchumi wa taifa katika Mwaka 1989. Dar es Salaam: Planning Commission, President's Office, 1990.

(Accepted 24 February 1992)

\title{
Hyponatraemia and death or permanent brain damage in healthy children
}

\author{
Allen I Arieff; J Carlos Ayus, Cosmo L Fraser
}

\section{Abstract}

Objective-To determine if hyponatraemia causes permanent brain damage in healthy children and, if so, if the disorder is primarily limited to females, as occurs in adults.

Design-Prospective clinical case study of 16 affected children and a review of 24412 consecutive surgical admissions at one medical centre.

Patients - 16 children (nine male, seven female; age 7 (SD 5) years) with generally minor illness were electively hospitalised for primary care. Consultation was obtained for the combination of respiratory arrest with symptomatic hyponatraemia (serum sodium concentration $\leq 128 \mathrm{mmol} / \mathrm{l}$ )

Main outcome measures-Presence, gender dis-

University of California School of Medicine, San Francisco, California Allen I Arieff, professor of medicine

Cosmo L Fraser, associate professor of medicine

\section{Baylor College of} Medicine, Houston, Texas $\mathrm{J}$ Carlos Ayus, professor of medicine

Correspondence to: Professor Allen I Arieff, Department of Medicine, Veterans Affairs Medical Center $(111 \mathrm{G})$, San Francisco, CA 94121, USA.

BMF 1992;304:1218-22 cerebral oedema detected at either radiological or postmortem examination. All 15 patients not treated for their hyponatraemia in a timely manner either died or were permanently incapacitated by brain damage. The only patient treated in a timely manner was alive but mentally retarded.

Conclusions-Symptomatic hyponatraemia can result in a high morbidity in children of both genders, which is due in large part to inadequate brain adaptation and lack of timely treatment.

\section{Introduction}

In previous studies from our laboratories we have described the symptomatology, clinical course, effects of treatment, and pathological findings in more than 225 adults (aged over 16) with symptomatic hyponatraemia..$^{1-8}$ Although the actual incidence of hyponatraemia seems to be similar among men and women, ${ }^{89}$ almost all adult patients suffering hyponatraemic brain damage are women. Although there are a number of reported paediatric cases of hyponatraemia, ${ }^{10-12}$ there are few reported cases of death or permanent brain damage among children with this disorder, ${ }^{13}{ }^{14}$ and most such children had pre-existing neurological disorders. ${ }^{15-17}$ Neither the gender distribution nor the incidence of brain damage among children with hyponatraemia is known. ${ }^{10} 12-17$ Among children suffering brain damage from hyponatraemia neither the type nor the gender distribution is known. We describe both a prospective and a retrospective analysis of generally healthy children who were elect- 
ively hospitalised. Sixteen children who developed severe symptomatic hyponatraemia either died or suffered permanent brain damage. Unlike the situation in adults, both males and females were adversely affected among these children.

\section{Patients and methods}

Prospective studies-Over a period of six years (198490) we were consulted about 16 previously healthy children (aged under 16) who had developed symptomatic hyponatraemia and either died or suffered permanent brain damage. These 16 patients were seen in consultation from five tertiary and nine community hospitals. The age of the children was 7 (SD 5) years (range 1.5 to 15 years), and the gender distribution was nine males and seven females. The mean weight was $23.8(12.9) \mathrm{kg}$ (range 10 to $52 \mathrm{~kg}$ ). Symptomatic hyponatraemia developed within five days of admission to the hospital.

Epidemiological studies-We retrospectively studied all surgical admissions to a 456 bed tertiary paediatric university teaching hospital over three years (1989-91). The records of all paediatric (age under 16) surgical patients were evaluated for those who had postoperative hyponatraemia (serum sodium concentration 128 $\mathrm{mmol} / \mathrm{l}$ or less) and the number who either died or suffered permanent brain damage as a result of the hyponatraemia. The epidemiological data were generated by computer search of the hospital records using the SAS database ${ }^{18}$ to obtain information on all paediatric surgical patients who had a postoperative serum sodium concentration of $128 \mathrm{mmol} / \mathrm{l}$ or less. There were 24412 consecutive inpatient operations over the three years ended 31 December 1991. In addition, we calculated an approximation of the incidence of hyponatraemic brain damage in children in the United States from our epidemiological data plus a statistical database from the medical literature. ${ }^{19} 20$

\section{Results \\ STUDY PATIENTS}

The table shows the clinical circumstances which resulted in hospitalisation of the 16 patients. All data are presented as means (SD). Symptoms were not known in three patients, who were either too young (less than 18 months) or intubated and thus unable to vocalise any complaints. Of the remaining 13 patients, 11 had progressive lethargy, weakness, nausea, and emesis and 12 had headache. All patients suffered respiratory arrest after a mean of 37 hours (range three to 120 hours) from the start of intravenous fluid administration.

\section{CLINICAL COURSE}

At admission the serum sodium concentration was 138 (2) $\mathrm{mmol} / \mathrm{l}$. As early as two hours after starting hypotonic fluid administration those patients able to communicate became progressively more lethargic and complained of headache and nausea, with subsequent emesis. All such symptoms were generally unresponsive to conventional agents (phenothiazines and narcotics). After a mean of 37 hours all 16 patients suffered respiratory arrest, at which time the serum sodium concentration was $115(7) \mathrm{mmol} / \mathrm{l}$ and urine osmolality $676(66) \mathrm{mmol} / \mathrm{kg}$. This level of urine hypertonicity in the presence of hyponatraemia suggests that the plasma antidiuretic hormone concentration was raised..$^{21}$ The onset of respiratory arrest was often explosive in nature, and hyponatraemia was generally not considered as a possible cause.

Immediately after respiratory arrest but before oxygen administration or intubation the arterial oxygen tension was evaluated in 11 patients and was $6.0(1.5) \mathrm{kPa}$. During the 37 hours between the time of admission and onset of respiratory arrest the patients had received a mean of $125(83) \mathrm{ml}$ hypotonic intravenous fluids per $\mathrm{kg}$ daily. Urine output was $34(34) \mathrm{ml} /$ $\mathrm{kg}$ per day and other fluid losses averaged $28(25) \mathrm{mL} / \mathrm{kg}$ per day (nasogastric suction, $n=2$; emesis, $n=10$; cerebrospinal fluid drainage, $n=1$; not charted, $n=3$ ) with mean net output of $74(82) \mathrm{ml} / \mathrm{kg}$ daily and net positive fluid balance of only 27 (14) $\mathrm{ml} / \mathrm{kg}$ per day. Hyponatraemia in these children was thus largely due to extensive extrarenal loss of electrolyte containing fluids with replacement by hypotonic fluids. Most of the intravenous fluids were administered as $280 \mathrm{mmol}$ glucose per litre either in water or in sodium chloride $38 \mathrm{mmol} / \mathrm{l}$, but the plasma glucose concentration was

Clinical characteristics of 16 children with symptomatic hyponatraemia

\begin{tabular}{|c|c|c|c|c|c|c|c|c|c|c|c|c|}
\hline \multirow{2}{*}{$\begin{array}{l}\text { Case } \\
\text { No }\end{array}$} & \multirow{2}{*}{$\begin{array}{l}\text { Gender } \\
\text { and age } \\
\text { (years) }\end{array}$} & \multirow{2}{*}{$\begin{array}{l}\text { Weight } \\
(\mathrm{kg})\end{array}$} & \multicolumn{2}{|c|}{$\begin{array}{l}\text { Serum sodium } \\
(\mathrm{mmol} / \mathrm{l})\end{array}$} & \multirow{2}{*}{$\begin{array}{l}\text { Duration of } \\
\text { intravenous } \\
\text { fluid } \\
\text { treatment } \\
\text { (hours) }\end{array}$} & \multirow{2}{*}{$\begin{array}{c}\text { Net fluid } \\
\text { intake }(\mathrm{ml} / \mathrm{kg})\end{array}$} & \multirow{2}{*}{$\begin{array}{l}\text { Net fluid } \\
\text { output } \\
\left(\mathrm{ml} / \mathrm{kg} /{ }^{\star}\right.\end{array}$} & \multirow[b]{2}{*}{ Clinical history } & \multirow{2}{*}{ Hospital procedures } & \multirow{2}{*}{$\begin{array}{l}\text { Respiratory } \\
\text { arrest }\end{array}$} & \multirow{2}{*}{$\begin{array}{l}\text { Treatment after } \\
\text { respiratory arrest }\end{array}$} & \multirow[b]{2}{*}{ Clinical outcome } \\
\hline & & & Initial & Lowest & & & & & & & & \\
\hline 1 & M 3.5 & $2 \cdot 27$ & 139 & 114 & 46 & 246 & 222 & $\begin{array}{l}\text { Fever, dysphagia, } \\
\text { pharyngitis, tonsilitis }\end{array}$ & Antibiotics + fluids & Yes & $\begin{array}{l}154 \mathrm{mM} \text { sodium } \\
\text { chloride }\end{array}$ & $\begin{array}{l}\text { Vegetative, } \\
\text { quadriplegia }\end{array}$ \\
\hline 2 & F 5 & $18 \cdot 0$ & 141 & 123 & 14 & 96 & 33 & Tonsillitis & Tonsillectomy & Yes & None & Died \\
\hline 3 & $\mathrm{~F} 4$ & $18 \cdot 2$ & 139 & 115 & 21 & 114 & NA & Tonsillitis & Tonsillectomy & Yes & None & Died \\
\hline 4 & M 15 & $44 \cdot 6$ & 134 & 101 & 74 & 164 & 73 & $\begin{array}{l}\text { Fever, dysphagia, } \\
\text { pharyngitis, tonsilltis }\end{array}$ & Antibiotics + fluids & Yes & $\begin{array}{l}154 \text { and } 514 \mathrm{mM} \\
\text { sodium chloride }\end{array}$ & $\begin{array}{l}\text { Aspiration } \\
\text { pneumonia, sepsis, } \\
\text { died }\end{array}$ \\
\hline 5 & M 3.5 & $15 \cdot 0$ & 138 & 121 & 9 & 61 & 5 & Tonsillitis & Tonsillectomy & Yes & None & Died \\
\hline 6 & F 12 & $31 \cdot 8$ & 137 & 120 & 33 & 57 & 11 & $\begin{array}{l}\text { Elbow fracture from } \\
\text { car accident }\end{array}$ & Setting of fracture & Yes & $\begin{array}{l}514 \mathrm{mM} \text { sodium } \\
\text { chloride; } \\
\text { intubation }\end{array}$ & $\begin{array}{l}\text { Ambulatory, mental } \\
\text { retardation }\end{array}$ \\
\hline 7 & M4 & $16 \cdot 4$ & 139 & 118 & 27 & 109 & 88 & Elbow fracture from fall & Setting of fracture & Yes & None & Died \\
\hline 8 & M 3 & $10 \cdot 0$ & 137 & 113 & 8 & 300 & NA & $\begin{array}{l}\text { Stricture of urethra; } \\
\text { tonsillits }\end{array}$ & $\begin{array}{l}\text { Urethral dilatation; } \\
\text { tonsillectomy }\end{array}$ & Yes & None & Died \\
\hline 9 & F 1.5 & $10 \cdot 6$ & 137 & 114 & 120 & 283 & 253 & Hydrocephalus & $\begin{array}{l}\text { Ventriculoperitoneal } \\
\text { shunting }\end{array}$ & Yes & None & Vegetative \\
\hline 10 & M 9 & $27 \cdot 0$ & 137 & 120 & 32 & 79 & NA & $\begin{array}{l}\text { Fractures from car } \\
\text { accident }\end{array}$ & $\begin{array}{l}\text { Operative setting of } \\
\text { fractures }\end{array}$ & Yes & None & Vegetative \\
\hline 11 & F 15 & $52 \cdot 0$ & 138 & 102 & 94 & 87 & 57 & $\begin{array}{l}\text { Fractures from car } \\
\text { accident }\end{array}$ & $\begin{array}{l}\text { Operative setting of } \\
\text { fractures }\end{array}$ & Yes & $\begin{array}{l}154 \mathrm{mM} \text { sodium } \\
\text { chloride; } \\
\text { intubation }\end{array}$ & Vegetative and blind \\
\hline 12 & F 4 & $16 \cdot 8$ & 138 & 107 & 16 & 88 & 56 & Tonsillitis & Tonsillectomy & Yes & None & Died \\
\hline 13 & M 2 & $11 \cdot 4$ & 138 & 116 & 3 & 123 & NA & Undescended testicle & Orchiopexy & Yes & None & Died \\
\hline 14 & M 6 & $15 \cdot 0$ & 138 & 119 & 12 & 40 & 11 & Severe epistaxis & Posterior packing & Yes & None & Died \\
\hline 15 & M 12 & $42 \cdot 0$ & 137 & 123 & 19 & 34 & 9 & $\begin{array}{l}\text { Fever, appendicitis, } \\
\text { ruptured appendix }\end{array}$ & $\begin{array}{l}\text { Appendicectomy plus } \\
\text { drainage }\end{array}$ & Yes & None & Died \\
\hline 16 & F 12 & $28 \cdot 5$ & 134 & 116 & 66 & 113 & 72 & Pneumonia & Antibiotics + fluids & Yes & None & Vegetative \\
\hline Mean & 7 & $23 \cdot 8$ & 138 & 115 & 37 & 125 & 74 & & & & & \\
\hline SD & 5 & $12 \cdot 9$ & 2 & 7 & 34 & 83 & 82 & & & & & \\
\hline SE & 1 & $3 \cdot 2$ & 1 & 2 & 9 & 21 & 24 & & & & & \\
\hline
\end{tabular}

«Urine+emesis + gastric drainage + cerebrospinal fluid. NA=Not available 
only $7 \cdot 0(0.7) \mathrm{mmol} / \mathrm{l}$ at the time hyponatraemia was diagnosed. Four patients (two male, two female) subsequently developed the syndrome of central diabetes mellitus and central diabetes insipidus ${ }^{5}$ with hypotonic polyuria. In these four patients the mean serum sodium concentration rose (without treatment) from $114(6) \mathrm{mmol} / \mathrm{l}$ to $164 \mathrm{mmol} / \mathrm{l}$ and the glucose concentration to $31 \cdot 1 \mathrm{mmol} / \mathrm{l}$. None of these patients had been treated for their hyponatraemia.

\section{OUTCOME}

All 16 patients either died or suffered permanent brain damage (table): one was mentally retarded, 10 died, and five were in a persistent vegetative state which persisted for follow up intervals of at least two years. Twelve patients received no specific treatment for their hyponatraemia. Of these, nine died and three remained in a persistent vegetative state. ${ }^{22}$ Four patients were eventually treated with intravenous sodium chloride 154 and $514 \mathrm{mmol} / \mathrm{l}$ (table) such that the serum sodium concentration was increased from 108 (9) to 138 (4) $\mathrm{mmol} / \mathrm{l}$ in 44 hours. The average delay from respiratory arrest to start of treatment was eight hours, all four patients were comatose, apnoeic, and intubated at the time treatment was begun, and none awoke either during treatment or for three days thereafter. Only one patient (case 6), who survived mentally retarded, was treated within 10 minutes of respiratory arrest.

\section{NECROPSY FINDINGS}

Postmorten examination of the brain was performed in 10 patients (three girls, seven boys). In nine patients who had received no treatment and died in less than 48 hours there was cerebral oedema and herniation on gross examination of the brain. The brain weight (unfixed) in six patients (three male, three female) whose mean age was 3.8 years was 1354 (95) g. For comparison, the normal brain weight in men is $1450 \mathrm{~g}$, in women $1250 \mathrm{~g}$, in 4-5 year old boys $1300 \mathrm{~g}$, and in 4-5 year old girls $1150 \mathrm{~g} .{ }^{23}$ Thus brain weight was increased by more than $10 \%$ above control values for children of the age range studied..$^{23}$ That transtentorial herniation was present in all nine patients subjected to postmortem evaluation correlates well with the observation that the human brain can expand by only about $5-7 \%$ of its normal volume ${ }^{24}$ before herniation occurs. We have shown that men's brains can usually adapt to hyponatraemia within a few hours whereas women's brains may not adapt within several days. ${ }^{8}$ In all 16 children presented here the brains were unable adequately to adapt to hyponatraemia.

\section{EPIDEMIOLOGICAL FINDINGS}

Among 24412 paediatric surgical admissions to a 456 bed university paediatric hospital there were 83 $(0.34 \%)$ patients who developed hyponatraemia. Among these, seven $(8.4 \%)$ died of complications of the hyponatraemia. Among the seven deaths, four were in boys and three in girls. Hence the incidence was 340 cases of paediatric postoperative hyponatraemia and 29 hyponatraemic deaths per 100000 inpatient operations on children. There are 2.02 million paediatric inpatient operations a year in the United States. ${ }^{192025}$ The estimated yearly incidence in the United States is 7448 cases of paediatric postoperative hyponatraemia, with 626 such hyponatraemic deaths in children. The most common inpatient operations on children in the United States ${ }^{20}$ are to the nose, mouth, and pharynx (17\%); digestive system (17\%); musculoskeletal system (15\%); and nervous system (13\%), of which $43 \%$ are performed in girls. This was essentially the distribution in our series, in which $92 \%$ of operations were in these four groups and $44 \%$ of the patients were female (table).

\section{Discussion}

These cases show that generally healthy children with symptomatic hyponatraemia (101-123 mmol/l) can abruptly develop respiratory arrest and either die or develop permanent brain damage. The permanent brain damage can include pituitary infarction with resultant central diabetes insipidus and mellitus, a syndrome not previously described in children. ${ }^{5}$ The incidence of postoperative hyponatraemia in children $(0 \cdot 34 \%)$ was less than in adults $(1-4 \%){ }^{821}$ However, among paediatric patients who developed symptomatic hyponatraemia the incidence of permanent brain damage was substantially higher than in adults. ${ }^{821}$ Both the types of surgery and gender distribution among our 16 patients (table) were the same as the most common operations and gender distribution in the United States as a whole,,$^{20}$ and thus our 16 patients were representative of the spectrum of elective paediatric surgical patients.

The hyponatraemia in these children seems to have been caused by extensive extrarenal loss of electrolyte containing fluids and intravenous replacement with hypotonic fluids (table) in the presence of antidiuretic hormone activity. Increased plasma concentrations of antidiuretic hormone are usually found in both children and adults with hyponatraemia, ${ }^{92-141626}$ and the hormone has multiple cerebral and vascular effects which can impair the ability of the brain to adapt to hyponatraemia. ${ }^{27}$ However, the genesis of hyponatraemia in children is usually different from that in adults. In adults there has often been administration of very large quantities of intravenous fluid (net retention $63 \mathrm{ml} / \mathrm{kg}$ per day in adults $v 28 \mathrm{ml} / \mathrm{kg}$ per day in children; $\mathrm{p}<0.01)^{35}$ or diuretic induced loss of cations. ${ }^{2629}$ It is important to recognise that in children, when there is substantial extrarenal loss of electrolytes, a minimal positive balance of hypotonic fluid can lead to fatal hyponatraemia. Another major factor which may have contributed to the high morbidity among these children was the virtual absence of timely treatment in the presence of obvious symptoms. ${ }^{10111617}$ Furthermore, the types of operations and the clinical conditions in this patient population were similar to those most common in the United States. ${ }^{20}$ Thus the index of suspicion for electrolyte disorders in generally healthy children undergoing elective surgery may be quite low.

\section{BRAIN ADAPTATION TO HYPONATRAEMIA IN CHILDREN}

In adults oestrogens seem to impair the ability of the brain to adapt to hyponatraemia and androgens may augment such adaptation. ${ }^{30-33}$ However, prepubescent children have only minimal to absent concentrations of either hormone, thus negating such effects. Most adults suffering permanent brain damage from hyponatraemia are female, ${ }^{3578}$ but in the current series a minority of affected patients $(43 \%)$ in both the prospective and retrospective studies were female. Thus unlike the marked gender differential in adults, male and female children seem to be at similar risk of developing hyponatraemia encephalopathy (NS $\left(\chi^{2}\right.$ test)). Furthermore, neither the actual concentration of serum sodium nor the rapidity of development of hyponatraemia seemed to predict the ultimate outcome in these 16 children (table). Hyponatraemia developed over a mean of 37 hours and the range of serum sodium values was $101-123 \mathrm{mmol} / \mathrm{l}$, values quite similar to those previously reported in children with symptomatic hyponatraemia who did not develop brain damage..$^{10121316}$

\section{EFFECTS OF PHYSICAL FACTORS}

When hyponatraemia was present all 16 children had radiological evidence (computed tomography, magnetic resonance imaging) of cerebral oedema 
whereas at necropsy nine of 10 evaluated had cerebral oedema with herniation. These findings show that adequate adaptation of the brain to hyponatraemia had not occurred. There are several unique characteristics of the paediatric central nervous system which may impair the ability to adapt to hyponatraemia. Such characteristics may include physical factors resulting from differences in the ratio of intracranial capacity to brain size, cerebrospinal fluid volume, and brain water and electrolyte content.

The early adaptation of brain to hyponatraemia involves a loss of blood and cerebrospinal fluid followed by extrusion of sodium from brain cells. ${ }^{34} 35$ Later adaptation includes loss of potassium and possibly amino acids, which act further to decrease brain cell osmolality and limit the gain of water. ${ }^{134}$ In humans and laboratory animals brain water content is more than 2.5 times higher in the young, decreasing progressively with age.$^{36-38}$ In children the ratio of brain to skull size is such that there is less room for expansion of the paediatric brain in the skull than there is in adults. ${ }^{39}$ As adults age there is a progressive decline in the brain volume whereas skull size remains constant. ${ }^{39}$ Hence anatomically there is decreased room for expansion of the brain within the skull in children as compared with adults. ${ }^{23}$

Adult brain size is reached at about age 6 whereas full skull size is not reached until age 16. Additionally, the intracerebral volume of cerebrospinal fluid is more than $10 \%$ greater in adults than in the young. ${ }^{39}$ When brain swelling occurs the intracerebral loss of cerebrospinal fluid increases the available volume in which the brain can expand. ${ }^{35}{ }^{40}$ As the percentage of cerebrospinal fluid in the brain increases with age ${ }^{3839}$ adults of both genders have more room in the rigid skull for the brain to expand than do children. ${ }^{39}$ Furthermore, the brain intracellular concentration of sodium is about $27 \%$ higher in children than in adults ${ }^{37}$ and may reflect a relative decreased ability to pump sodium out of the brain in children. In the presence of hyponatraemia this will result in a greater osmolar gap between brain and plasma in the young. It has been shown that in newborn puppies with hyponatraemia the brain is unable to extrude cations ${ }^{38}$ whereas adult animals with hyponatraemia can readily transport sodium out of the brain. ${ }^{13134}$

\section{PREVENTION AND TREATMENT OF HYPONATRAEMIC ENCEPHALOPATHY}

Symptomatic hyponatraemia can best be prevented by not infusing hypotonic fluids to hospitalised children unless there is a clear cut indication for their use. Headache, nausea, emesis, weakness, and lethargy are consistent symptoms of hyponatraemia in children. If the condition is allowed to go untreated there can follow an explosive onset of respiratory arrest, coma, and transtentorial cerebral herniation. At present there is no way to predict which children may suffer respiratory arrest. As found recently in adults neither the magnitude of hyponatraemia nor its duration is the major determinant of brain damage. ${ }^{8}$ Recent studies show that recovery from symptomatic hyponatraemia in children, even after the onset of seizures and apnoea, may be possible if appropriate treatment is instituted in a timely manner. ${ }^{\prime \prime}$

When a paediatric patient receiving hypotonic fluids begins to have headache, emesis, nausea, or lethargy the serum sodium concentration must be measured. Although these symptoms are somewhat non-specific, the diagnosis is easily established at minimal cost and with virtually no risk to the patient by evaluating plasma electrolyte values. When symptomatic hyponatraemia is diagnosed the patient should be moved to a location where constant monitoring can be provided, such as the intensive therapy unit. Hypertonic sodium chloride $(514 \mathrm{mmol} / \mathrm{l})$ should be infused as described, ${ }^{411}{ }^{41}$ such that the serum sodium concentration is increased to $125-130 \mathrm{mmol} / \mathrm{l}$ but by no more than 25 mmol in the initial 48 hours. In addition to hypertonic sodium chloride, treatment may include intubation and assisted mechanical ventilation when required.

This work was supported by grant RO1 08575-01A2 from the National Institute on Aging, National Institutes of Health, Bethesda, Maryland, and by the research service of the Veterans Affairs Medical Center, San Francisco, California. We thank Anne Ludvik and Trish Sullivan, of the library service at the San Francisco Veterans Affairs Medical Center, for help in preparing the database and the medical records department of the Children's Hospital, Houston, Texas, for help in preparing the statistical data.

\section{Addendum}

After submission of this paper a report appeared describing 34 paediatric patients with water intoxication. ${ }^{42}$ Two of the patients became hyponatraemic secondary to intravenous hypotonic fluid administration (serum sodium concentrations 112 and $114 \mathrm{mmol} / \mathrm{l}$ ). Both suffered respiratory arrest and died, and at necropsy both had cerebral oedema. These two patients had a clinical course similar to the 16 in our series. The other 32 patients had oral water intoxication, and all survived because of timely and appropriate treatment.

1 Arieff AI, Llach F, Massry SG, Kerian A. Neurological manifestations and morbidity of hyponatremia: correlation with brain water and electrolytes. morbidity of hyponatremia: correlation

2 Ayus JC, Olivero JJ, Frommer JP. Rapid correction of severe hyponatremia with intravenous hypertonic saline solution. Am F Med 1982;72:43-8.

3 Arieff AI. Hyponatremia, convulsions, respiratory arrest, and permanen brain damage after elective surgery in healthy women. $N$ Engl $\mathcal{F ~ M e d}$ 1986;314:1529-35.

4 Ayus JC, Krothapalli RK, Arieff AI. Treatment of symptomatic hyponatremi and its relation to brain damage. A prospective study. $N$ Engl $\mathcal{F}$ Med 1987;317:1190-5

5 Fraser $\mathrm{CL}$, Arieff AI. Fatal central diabetes mellitus and insipidus resultin from untreated hyponatremia: a new syndrome. Ann Intern Med 1990;112: 113-9.

6 Ashraf N. Locksley R, Arieff AI. Thiazide-induced hyponatremia associated with death or neurologic damage in outpatients. Am J Med 1981;70:1163-8.

7 Tien R, Arieff AI, Kucharczyk W, Wasik A, Kucharczyk J. Hyponatremic brain damage: is central pontine myelinolysis common? Am $\mathcal{J} \mathrm{Med}$ (in press).

8 Ayus JC, Arieff AI. Effects of age and gender on outcome in patients with postoperative hyponatremia. I Am Soc Nephrol 1991;2:278.

9 Gross PA, Pehrisch H, Rascher W, Schömig A, Hackenthal E, Ritz E. Pathogenesis of clinical hyponatremia: observations of vasopressin and fluid intake in 100 hyponatremic medical patients. Eur f Clin Invest 1987;17: 123-9.

10 Crumpacker RW, Kriel RL. Voluntary water intoxication in normal infants. Neurology 1973;23:1251-5.

11 Sarnaik AP, Meert K, Hackbarth R, Fleischmann L. Management of hyponatremic seizures in children with hypertonic saline: a safe and effective strategy. Crit Care Med 1991;19:758-62.

12 David R, Ellis D, Gartner JC. Water intoxication in normal infants: role of antidiuretic hormone in pathogenesis. Pediatrics 1981;68:349-53.

13 Judd BA, Haycock GB, Dalton N, Chantler C. Hyponatraemia in premature babies and following surgery in older children. Acta Paediatr Scand 1987;76:385-93.

14 Cowley DM, Pabari M, Sinton TJ, Johnson S, Carroll G, Ryan WE. Pathogenesis of postoperative hyponatremia following correction of scoliosi in children. Aust N Z F Surg 1988;58:485-9.

15 Crawford JD, Dodge PR. Complications of fluid therapy in neurologic disease. Pediatr Clin North Am 1964;11:1029-52.

16 Burrows FA, Shatack JG, Crone RK. Inappropriate secretion of antidiuretic hormone in a postsurgical pediatric population. Crit Care Med 1983;11: $527-31$.

17 Varavithya W, Hellerstein S. Acute symptomatic hyponatremia. $\mathcal{F}$ Pediat 1967;71:269-83.

8 SAS Institute I. SAS user's guide: basics. Version 5 edition. Cary, Nort Carolina: SAS Institute, 1985

19 American Hospital Association. 1989 Annual survey of hospitals. Utilization, personnel and finances in US registered hospitals. In: American Hospital Association hospital statistics. Chicago: American Hospital Association, 1991:20 (table 5A).

20 US Department of Commerce. Population. In: Statistical abstracts of the United States, 1990. 110th ed. Washington, DC: Bureau of the Census, 1990: 16-8.

21 Chung HM, Kluge R, Schrier RW, Anderson RJ. Postoperative hyponatremia: a prospective study. Arch Intern Med 1986;146:333-6.

22 Jennett B, Plum F. Persistent vegetative state after brain damage. Lancet 1972;i:734-7.

23 Dekaban AS, Sadowsky D. Changes in brain weights during the span of human life: relation of brain weights to body heights and body weights. Ann Neurol 1978;4:345-56.

24 Garcia JH, Conger KA, Morawetz R, Halsey JH Jr. Postischemic brain edema quantitation and evolution. In: Cervós-Navarro J, Ferszt R, ed. Brai edema. Pathology, diagnosis, and therapy. New York: Raven Press, 1980: 147-69.

25 US Department of Commerce. Health and nutrition. In: Statistical abstracts of the United States, 1990. 110th ed. Washington, DC: Bureau of the Census, 1990:110-1.

26 Anderson RJ, Chung HM, Kluge R, Schrier RW. Hyponatremia: a prospec- 
tive analysis of its epidemiology and the pathogenetic role of vasopressin Ann Intern Med 1985;102:164-8.

27 Rosenberg GA, Estrada E, Kyner WT. Vasopressin-induced brain edema is mediated by the V1 receptor. Adv Neurol 1990;52:149-5

28 Faraci FM, Mayhan WG, Heistad DD. Effect of vasopressin on production of cerebrospinal fluid: possible role of vasopressin (V1)-receptors. Am F Physiol 1990;258:R94-8.

29 Abramow M, Cogan E. Clinical aspects and pathophysiology of diureticinduced hyponatremia. Adv Nephrol (Paris) 1984:13:1-28.

30 Guerra $\mathrm{M}$, del Castillo AR, Batraner $\mathrm{E}$ Mas M Androgens stimulate preoptic are $\mathrm{Na}+\mathrm{K}+\mathrm{ATPase}$ activity in male rats. Neurosci Len 1987;78:97-100.

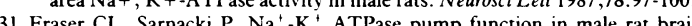
synaptosomes is different from that of females. Am $\mathcal{F}$ Physiol 1989;257: E284-9.

32 Fraser CL, Kucharczyk J, Arieff AI, Rollin C, Sarnacki P, Norman D. Sex differences result in increased morbidity from hyponatremia in female rats. Am f Physiol 1989;256:R880-5.

33 Del Castillo AR, Battaner E, Guerra M, Alonso T, Mas M. Regional changes of brain $\mathrm{Na}+, \mathrm{K}+$-transporting adenosine triphosphate related to ovarian function. Brain Res 1987;416:113-8.

34 Melton JE, Patlak CS, Pettigrew KD, Cserr HF. Volume regulatory loss of
$\mathrm{Na}, \mathrm{Cl}$, and $\mathrm{K}$ from rat brain during acute hyponatremia. Am $\mathrm{f}$ Physiol 1987;252:F661-9.

35 Melton JE, Nattie EE. Brain and CSF water and ions during dilutional and isosmotic hyponatremia in the rat. Am $\mathcal{F}$ Physiol 1983;244:R724-32.

36 Widdowson EM, Dickerson JWT. The effect of growth and function on the chemical composition of soft tissues. Biochem $\mathcal{F}$ 1960;77:30-43.

37 Katzman R, Pappius HM, eds. Brain ions. In: Brain electrolytes and fluid metabolism. Baltimore: Williams and Wilkins, 1973:111-34.

38 Nattie EE, Edwards WH. Brain and CSF water in newborn puppies during acute hypo-and hypernatremia. $\mathcal{F}$ Appl Physiol 1981;51:1086-91.

39 Gur RC, Mozley PD, Resnick SM, Gottlieb GL, Kohn M, Zimmerman R, ex al. Gender differences in age effect on brain atrophy measured by magnetic
a resonance imaging. Proc Natl Acad Sci USA 1991;88:2845-9.

40 Rosomoff HL, Zugibe FT. Distribution of intracranial contents in experimental edema. Arch Neurol 1963;9:36-44.

41 Worthley LIG, Thomas PD. Treatment of hyponatraemic seizures with intravenous $29 \cdot 2 \%$ saline. BMF 1986;292:168-70.

42 Keating JP, Schears GJ, Dodge PR. Oral water intoxication in infants Am f Dis Child 1991;145:985-90.

(Accepted 6.March 1992)

\section{First use of heroin: changes in route of administration over time}

\author{
John Strang, Paul Griffiths, Beverly Powis, \\ Michael Gossop
}

Drug Transitions Study, National Addiction Centre, Maudsley Hospital, London SE5 8AF

John Strang, director Paul Griffiths, senior research worker

Beverly Powis, research worker

Michael Gossop, head of research

Correspondence to: Dr Strang.

BMF 1992;304:1222-3

AIDS and drug misuse are linked mainly by the injection of many drugs. Major changes in the methods of heroin use, however, have fundamentally altered the importance of heroin use in the transmission of HIV. Recent reports describe the extent of "chasing the dragon" (inhaling sublimated heroin after heating it on tinfoil) as a new route of heroin use but give no information on the emergence of this pattern. ${ }^{12}$ During the 1960s heroin use was by injecting. ${ }^{3}$ What events occurred (and when) to account for this substantial change in the nature and the link with HIV of the heroin epidemic?

\section{Subjects, methods, and results}

Four hundred heroin users were contacted and interviewed by trained peer group interviewers through a structured and tape recorded interview. A total of 204 $(51 \%)$ were currently out of contact with any treatment service, $100(25 \%)$ were currently attending a drug

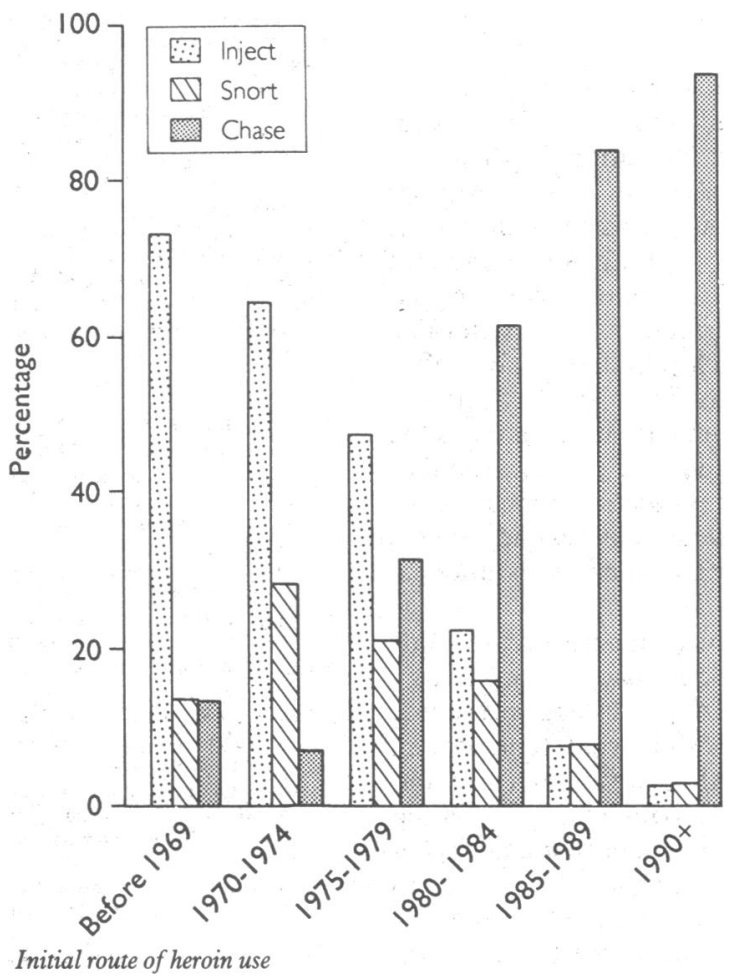

clinic, and $124(31 \%)$ were currently attending a needle exchange scheme. A total of $136(34 \%)$ had never had contact with either treatment services or an exchange scheme. Their ages ranged from 17 to 53 (mean (SD) $27 \cdot 6(6 \cdot 3)$ years); $248(62 \%)$ were male; $96(24 \%)$ were in current employment. There was wide variation in first year of use of heroin use (1954 to 1991): $16(4 \%)$ started during the ' $60 \mathrm{~s}, 28(7 \%)$ during the early ' 70 s, $76(19 \%)$ during the late ' 70 s, $124(31 \%)$ during the early ' 80 s, $120(30 \%)$ during the late ' 80 s, and $36(9 \%)$ during the ' $90 \mathrm{~s}$.

Three different routes of initial drug use were identified: injecting, snorting, and "chasing the dragon." Analysis of these data by year revealed a major change in the annual proportion who were initiated by either injecting or chasing (figure).

"Chasing" was a route of initiation for a minority of users up to the late 1970s but has become an increasingly common route of initiation since 1975 . By 1979 there were as many initiations by chasing as by injecting, and by 1981 more than half of the initiations into heroin use were by chasing (with the annual proportion remaining above half since 1981). By 1985 more than three quarters of initiations were by chasing, and since 1988,87 out of 93 initiations (94\%) were by chasing. During most years, a tenth to a quarter of users were initiated by snorting.

\section{Comment}

Heroin use today is not what it was yesterday. Initiation no longer occurs by injecting but by the new route of "chasing the dragon." The emergence of new non-injecting routes of heroin use may partly explain not only the major heroin epidemic in the United Kingdom during the 1980s but also its apparent continuation $^{4}$ despite the addition of AIDS as a potential consequence. Perhaps the protective societal taboo against injecting was circumvented and a less fettered epidemic has developed. In the 1990s virtually all initiations into heroin use in our London sample were by "chasing the dragon," even though heroin use in other countries (for example, the United States) and even in other British cities (for example, Edinburgh) continues to be by injection. Should the change in London be regarded as an isolated development in a few "chasing" cities, or is it an indication of likely future changes on a wider scale? And what is the significance for tomorrow's prevention and treatment programmes?

Our level of ignorance about changing routes of drug administration is not only scientifically disturbing but also interferes with the development of prevention and treatment programmes. Effective primary prevention strategies depend greatly on the adequacy of knowledge about the gateways into drug use, and yet our understanding of the phenomenon is informed. largely by . 